\title{
Pengaruh Kepemilikan Institusional Dan Kinerja Keuangan Terhadap Penghindaran Pajak Dengan Corporate Sosial Responsibility Sebagai Pemediasi
}

\author{
Adhitya Putri Pratiwi \\ Universitas Pamulang, Tanggerang, Indonesia \\ adhitya.putripratiwi@gmail.com
}

\begin{abstract}
This study aims to determine the effect of Institutional Ownership and Return On Assets on Tax Avoidance with Corporate Social Responsibility as an intervening variable. This research was conducted on plantation issuers listed on the Indonesia Stock Exchange in 2012-2016. The sample in this study was obtained using a purposive sampling technique and based on predetermined criteria, a sample of 14 plantation issuers was obtained. The analytical method used is path analysis with a significant level of $5 \%$. The results showed that Institutional Ownership variables did not significantly influence either directly or indirectly through Corporate Social Responsibility. While the Return On Asset variable significantly affects Tax Avoidance both directly and through Corporate Social Responsibility. This research also shows that Tax Avoidance has a significant effect on Corporate Social Responsibility.
\end{abstract}

\begin{abstract}
Abstrak
Penelitian ini bertujuan untuk mengetahui pengaruh Kepemilikan Institusional dan Return On Asset terhadap Penghindaran Pajak dengan Corporate Social Responsibility sebagai variable intervening. Penelitian ini dilakukan pada emiten perkebunan yang terdaftar di BEI tahun 2012-2016. Sampel dalam penelitian ini diperoleh dengan menggunakan teknik purposive sampling dan berdasarkan kriteria yang telah ditentukan maka diperoleh sample sebanyak 14 emiten perkebunan. Metode analisis yang digunakan adalah path analysis dengan tingkat signifikan sebesar 5\%. Hasil penelitian menunjukkan bahwa variabel Kepemilikan Institusional tidak berpengaruh secara signifika baik secara langsung maupun tidak langsung melalui Corporate Social Responsibility. Sedangkan variabel Return On Asset berpengaruh secara signifikan terhadap Penghindaran Pajak baik secara langsung maupun melalui Corporate Social Responsibility. Penelitian ini juga menunjukkan bahwa Penghindaran Pajak berpengaruh secara signifikan terhadap Corporate Social Responsibility.
\end{abstract}

Kata Kunci: kepemilikan institusional; corporate social responsibility; penghindaran pajak; return on asset

\section{PENDAHULUAN}

Perbedaan kepentingan mengenai perpajakan dari sisi perusahaan dengan pemerintah akan menimbulkan perusahaan sebagai wajib pajak berusaha untuk meminimalisir bahkan menghindari jumlah pajak terutang baik secara legal (tax avoidance) maupun illegal (tax evasion). Pajak merupakan pendapatan yang penting bagi pemerintahan sedangkan perusahaan akan berusaha mengelola beban pajaknya seminimal mungkin agar memperoleh laba yang maksimal. Tax avoidance merupakan usaha pengurangan pembayaran pajak secara legal dengan mencari celah yang terdapat pada peraturan perundang-undangan perpajakan. Meski penghindaran pajak tersebut legal, namun hal tersebut akan mengurangi pendapatan pemerintah dari sektor perpajakan sehingga pemerintah tidak menginginkan hal tersebut terjadi. Rasio pajak menunjukkan kemampuan pemerintah dalam mengumpulkan pendapatan pajak. Kinerja pemungutan pajak Negara yang semakin baik akan menyebabkan semakin baik pula rasio penerimaan pajak pada Negara tersebut. Rendahnya kesadaran masyarakat dalam membayar pajak tercermin dari angka tax ratio yang masih di level $11,9 \%$. Fenomena perbedaan kepentingan antara pemerintah dan wajib pajak serta tax ratio yang belum mencapai target dapat mengindikasikan adanya aktivitas penghindaran pajak yang cukup besar sehingga penerimaan pajak Negara Indonesia belum maksimal. 
Dilihat dari rendahnya tax ratio yang menggambarkan usaha penghindaran pajak yang cukup besar, perusahaan harus memiliki tata kelola yang baik. Tata kelola perusahaan yang baik ditandai dengan adanya kepemilikan institusional, kepemilikan manajerial, komite audit dan dewan komisaris i Kepemilikan Institusional Dan Kinerja Keuangan Terhadap Penghindaran Pajak Dengan Corporate Sosial Responsibility Sebagai Pemediasi ndependen yang mumpuni. Dengan tata kelola perusahaan yang baik diharapkan mampu meningkatkan kinerja keuangan perusahaan.

Adanya perusahaan selain banyak memberikan keuntungan bagi masyarakat, perusahaan juga memiliki persoalan sosial dan lingkungan dimana perusahaan itu berada seperti polusi udara, limbah maupun kebisingan. Adanya persoalan-persoalan tersebut mempengaruhi kesadaran masyarakat akan pentingnya melakukan tanggung jawab sosial atau corporate social responsibility (CSR). CSR merupakan salah satu hal yang penting untuk diungkapkan dalam Annual Report perusahaan. Oleh karena itu, seluruh perusahaan yang ada di Indonesia semakin dituntut untuk memberikan informasi yang transparan terkait aktivitas sosialnya, sehingga pengungkapan terhadap CSR diperlukan (Kurniawati, 2013).

\section{KERANGKA PENELITIAN \& HIPOTESIS}

\section{Tax Avoidance}

Tax Avoidance adalah pengaturan untuk meminimumkan atau menghilangkan beban pajak dengan mempertimbangkan akibat pajak yang ditimbulkan. Umumnya tax avoidance dihubungkan dengan usaha perencanaan pajak. Umumnya perencanaan pajak merujuk pada proses merekayasa usaha dan transaksi wajib pajak supaya utang pajak berada dalam jumlah minimal tetapi masih dalam bingkai peraturan perpajakan (Suandy, 2008)

\section{Agency Theory}

Teori Agensi menyatakan hubungan kontrak antara agen (manajemen suatu perusahaan) dan principal (pemilik perusahaan). Agen melakukan tugas-tugas tertentu untuk principal, principal mempunyai kewajiban untuk memberi imbalan pada si agen (Hendriksen dan Breda, 1992)

\section{Stakeholder Theory}

Stakeholder theory mengatakan bahwa perusahaan bukanlah entitas yang hanya beroperasi untuk kepentingannya sendiri namun harus memberikan manfaat bagi stakeholdernya seperti pemegang saham, kreditor, konsumen, supplier, pemerintah, masyarakat, analisis dan pihak lain. Perusahaan harus menjaga hubungan dengan stakeholdernya dengan mengakomodasi keinginan dan kebutuhan stakeholder, terutama stakeholder yang memiliki power terhadap kesediaan sumber daya yang digunakan untuk aktivitas operasional perusahaan, misalnya tenaga kerja, pasar ataupun produk perusahaan. Salah satu strategi untuk menjaga hubungan baik dengan stakeholder adalah dengan melakukan CSR, yang diharapkan keinginan dari stakeholder dapat terakomodasi dengan baik sehingga akan menghasilkan hubungan yang harmonis (Zanirah, 2015).

\section{Legitimacy Theory}

Ghozali dan Chariri menjelaskan bahwa hal yang melandasi legitimacy theory adalah kontrak sosial dengan masyarakat dimana perusahaan beroperasi dan menggunakan sumber ekonomi. Sesuai dengan pendapat Guthrie dan Parker, legitimacy theory adalah organisasi yang mendasarkan operasi bisnisnya pada lingkungan sosial perusahaan melalui kontrak sosial yang disetujui dan berbagai keinginan masyarakat sebagai bentuk penghargaan atas persetujuan organisasi dan keberlanjutan perusahaan. Dengan teori ini, perusahaan harus memperhatikan kepentingan dari berbagai pihak, bukan hanya dari pihak perusahaan saja. Semakin banyak perusahaan melakukan kegiatan sosial yang memberikan dampak positif dari pihak lain, akan membuat manfaat dan kemajuan tersendiri bagi pihak perusahaan. Untuk itu, sebagai suatu sistem yang mengedepankan keberpihakan kepada society, operasi perusahaan harus kongruen dengan harapan masyarakat (Retno dan Priantinah, 2014).

\section{Pengungkapan Corporate Social Responsibility}

Menurut Sembiring dalam Gemitasari (2013), tanggung jawab sosial perusahaan merupakan proses pengkomunikasian dampak sosial dan lingkungan dari kegiatan ekonomi organisasi terhadap kelompok khusus yang berkepentingan dan terhadap masyarakat secara keseluruhan.

Pengungkapan tanggung jawab sosial dinilai menurut standar GRI (Global Reporting Initiative) versi G3.1 yang diterbitkan tahun 2011 dan GRI versi G4 yang diterbitkan tahun 2013. Total item pengungkapan GRI-G3.1 adalah 84 item sementara 
GRI-G4 adalah 91 item. Dalam standar GRI-G3.1 (2011) dan GRI-G4 (2013) indikator kinerja dibagi menjadi 3 komponen utama, yaitu ekonomi, lingkungan, dan sosial mencakup praktik ketenagakerjaan dan kenyamanan bekerja, hak asasi manusia, masyarakat, tanggung jawab atas produk (www.globalreporting.org).

\section{Kepemilikan Institusional}

Kepemilikan institusional merupakan kepemilikan saham oleh pemerintah, institusi keuangan, institusi berbadan hokum, institusi luar negeri dan dana perwalian serta institusi lainnya. Institusi-institusi tersebut berwenang melakukan pengawasan atas kinerja manajemen.

\section{Kinerja Keuangan}

Menurut Fahmi (2012), pengertian dari kinerja keuangan adalah suatu analisis yang dilakukan untuk melihat sejauh mana suatu perusahaan telah menggunakan aturan-aturan pelaksanaan keuangan secara baik dan benar. Pengukuran kinerja keuangan diperlukan sebagai bahan acuan untuk perencanaan laba kedepan, sekaligus kemungkinan untuk mengganti manajemen jika manajemen lama dianggap kurang berhasil (Kasmir, 2012). Oleh karena itu, Rasio Profitabilitas sering disebut sebagai salah satu alat ukur kinerja manajemen. Dengan pernyataan tersebut dapat disimpulkan bahwa metode pengukuran kinerja keuangan dapat digunakan dengan menggunakan analisis laporan keuangan.

\section{Return On Asset (ROA)}

Rasio ini merupakan salah satu rasio profitabilitas yang akan digunakan untuk mengukur kinerja perusahaan. ROA menggambarkan kemampuan perusahaan untuk menghasilkan keuntungan dari setiap rupiah asset yang digunakan dan juga memberikan ukuran yang lebih baik atas profitabilitas perusahaan karena menunjukkan efektifitas manajemen dalam menggunakan aktiva untuk memperoleh pendapatan dan dapat menilai apakah perusahaan efisien dalam memanfaatkan aktiva yang dimiliki untuk menjalankan kegiatan operasional perusahaan. Semakin besar rasio ini semakin baik karena berarti semakin besar kemampuan perusahaan menghasilkan laba (Kuswadi, 2006). Rasio ini dihitung dengan membagi laba bersih terhadap total asset.

Perusahaan yang memiliki kinerja keuangan yang baik, akan identik dengan upaya-upaya untuk melakukan pengungkapan yang lebih luas. Perusahaan dengan kinerja yang tinggi akan meningkatkan nilai perusahaan dalam proses pembentukan image yang sangat berpengaruh untuk mendapatkan kepercayaan dari stakeholdernya.

\section{KERANGKA PEMIKIRAN}

\section{Variabel Independen}

Kepemilikan Institusional $\left(\mathrm{X}_{1}\right)$

\section{Variabel Independen}

Kinerja Keuangan $\left(\mathrm{X}_{2}\right)$
$\mathrm{H}_{1}$

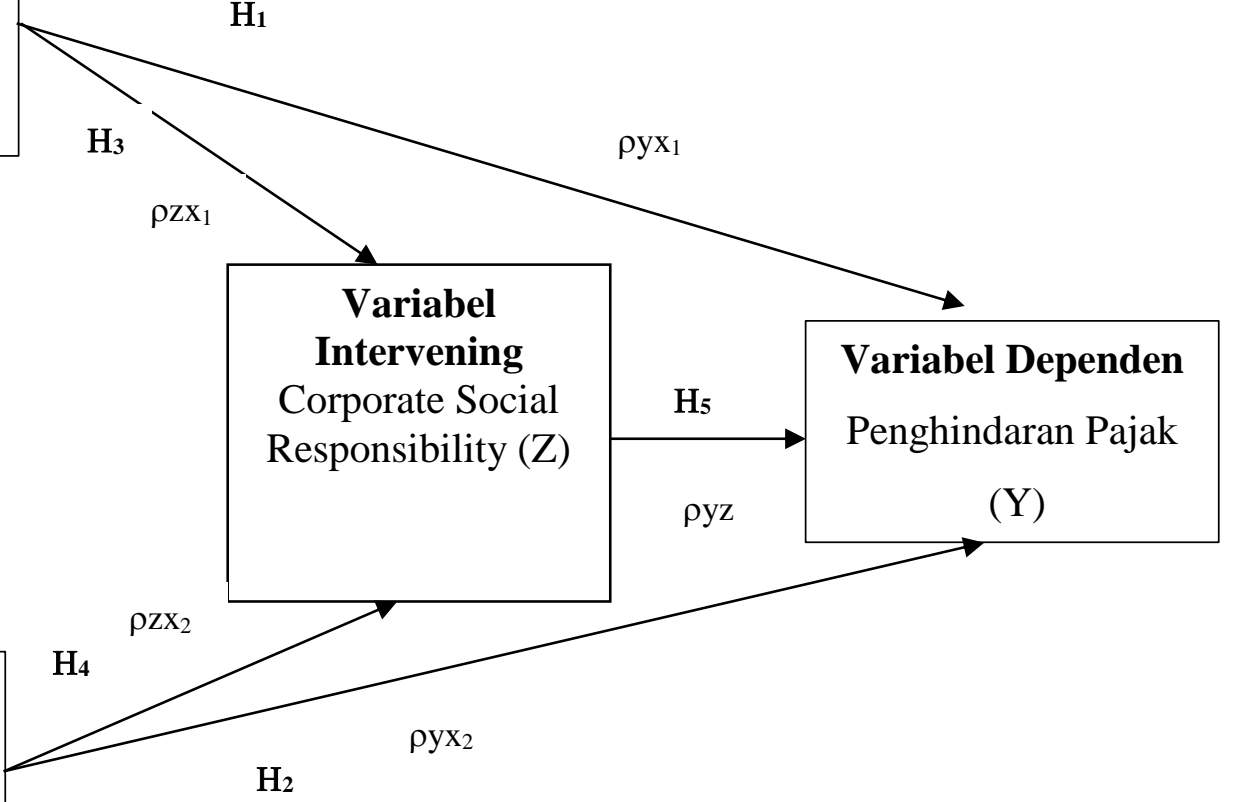


Adhitya Putri Pratiwi

Pengaruh Kepemilikan Institusional Dan Kinerja Keuangan Terhadap Penghindaran Pajak d engan Corporate Sosial Responsibility Sebagai Pemediasi 


\section{METODE PENELITIAN}

Populasi dalam penelitian ini adalah emiten sub sektor perkebunan yang terdaftar di Bursa Efek Indonesia (BEI) pada tahun 2012-2016. Dengan menggunakan metode purposive sampling yaitu metode pengambilan sampel berdasarkan kriteriakriteria tertentu, total sampel yang diperoleh adalah 50 sampel dari 10 perusahaan selama 5 tahun penelitian. Kriteria sampel yang ditetapkan adalah emiten sub sector perkebunan yang terdaftar di BEI tersebut melaporkan laporan tahunan (annual report) dan ringkasan laporan keuangan selama lima tahun berturut-turut.

\section{PENGOLAHAN DATA}

Analisis Statistik Deskriptif

Statistik deskriptif digunakan sebagai teknik analisis dengan tujuan untuk menjelaskan

atau memberikan gambaran mengenai variabelvariabel dalam penelitian.

TABEL 1

Analisis Statistik Deskriptif

\section{Descriptive Statistics}

\begin{tabular}{|l|r|r|r|r|r|}
\hline & $\mathrm{N}$ & \multicolumn{1}{|c|}{ Minimum } & \multicolumn{1}{c|}{ Maximum } & \multicolumn{1}{c|}{ Mean } & \multicolumn{1}{c|}{ Std. Deviation } \\
\hline Kepemilikan Institusioanl & 50 & 27.65 & 93.18 & 72.06 & 16.01 \\
Return On Asset & 50 &, 0034 &, 4363 &, 0635 &, 0734 \\
Penghindaran Pajak & 50 &, 4316 & 182.71 & 13.42 & 34.00 \\
Corporate Social Responsibili & 50 &, 56 & 1.00 &, 8196 &, 1381 \\
Valid N (listwise) & 50 & & & \\
\hline
\end{tabular}

Sumber : data penelitian diolah, 2018

\section{Uji Normalitas}

Uji normalitas bertujuan untuk melihat apakah data terdistribusi secara normal atau tidak. Dalam penelitian ini uji normalitas menggunakan analisis grafik normal p-plot. Pada dasarnya normalitas sebuah data dapat dikenali atau dideteksi dengan melihat persebaran data (titik) pada sumbu diagonal dari grafik histogram dari residualnya (1) Data dikatakan berdistribusi normal jika data menyebar disekitar garis diagonal dan mengikuti arah garis diagonal atau grafik histogramnya (2) Sebaliknya, data dikatakan tidak berdistribusi normal, jika data menyebar jauh dari arah garis atau tidak mengikuti diagonal atau grafik histogramnya.

Berikut ini adalah hasil uji normalitas :

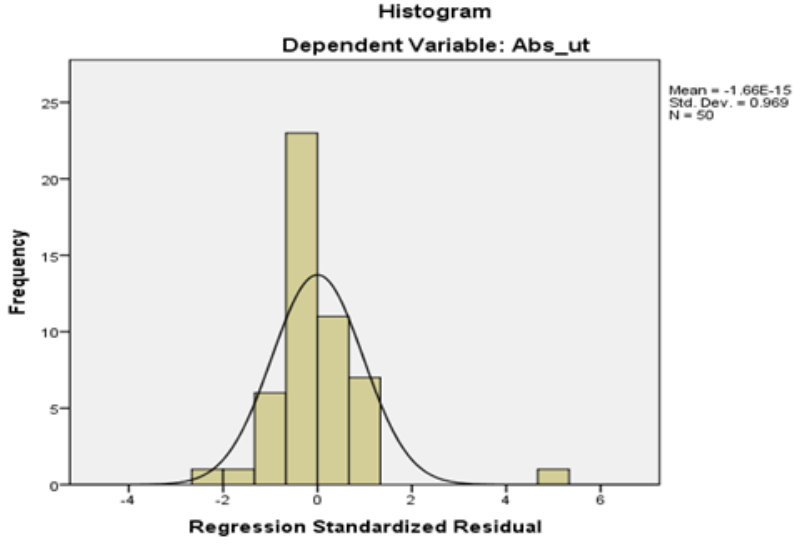

Gambar 2. Uji Normalitas Histogram

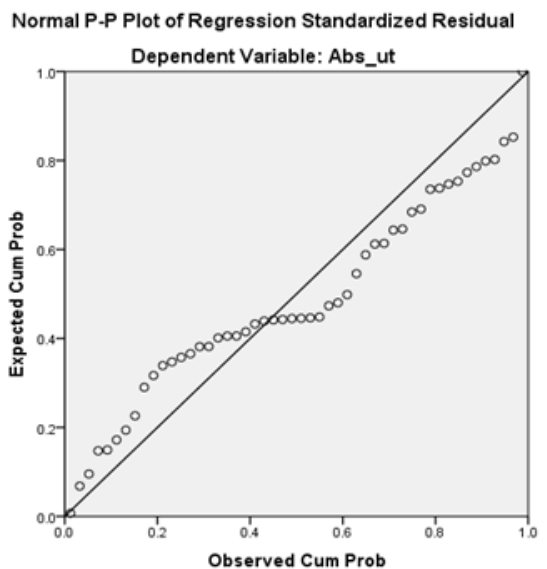

Gambar 3. Uji Normalitas P-Plot 


\section{Uji Autokorelasi}

Menurut Santoso (2012), uji autokorelasi digunakan untuk mengetahui apakah dalam sebuah model regresi linear ada korelasi antara kesalahan pengganggu pada periode $t$ dengan kesalahan pengganggu pada periode t-1 (sebelumnya). Pengambilan keputusan pada uji Durbin-Watson menurut Santoso (2012) adalah hal sebagai berikut :
1. Bila angka $\mathrm{DW}<-2$ berarti ada autokorelasi positif

2. Bila angka DW -2 sampai dengan +2 berarti tidak ada autokorelasi

3. Bila angka $\mathrm{DW}>+2$ berarti ada autokorelasi negative

Tabel 2 Uji Autokorelasi

Model Summary ${ }^{b}$

\begin{tabular}{|lc|r|r|r|r|}
\hline Model & R & R Square & $\begin{array}{r}\text { Adjusted } \\
\text { R Square }\end{array}$ & $\begin{array}{r}\text { Std. Error of the } \\
\text { Estimate }\end{array}$ & Durbin-Watson \\
\hline 1 & $.936^{\mathrm{a}}$ & 0.877 & 0.868 & 12.3322 & 1.416 \\
\hline
\end{tabular}

a. Predictors: (Constant), Corporate Social Responsibility, Return On Asset, Kepemilikan Institusioanl

\section{b. Dependent Variable: Penghindaran Pajak}

Sumber : data penelitian diolah, 2018

Hasil uji autokorelasi diatas menunjukkan bahwa nilai DW sebesar 1.416 atau berada diantara 2 sampai dengan +2 sehingga dapat disimpulkan bahwa tidak ada autokorelasi.

Uji Heterokedastisitas
Menurut Ghozali (2013), uji heterokedastisitas bertujuan untuk menguji apakah dalam model regresi terjadi ketidaksamaan variance dari residual satu pengamatan ke pengamatan yang lain. Jika korelasi antar variabel independen dengan residual didapat nilai signifikan lebih dari 0,05 maka dapat dikatakan bahwa tidak terjadi masalah heterokedastisitas pada model regresi.

Tabel 3 Uji Heterokedastisitas

Coefficients $^{\text {a }}$

\begin{tabular}{|ll|r|r|r|r|r|}
\hline & & \multicolumn{2}{|c|}{ Unstandardized Coefficients } & \multicolumn{2}{|c|}{ Standardized Coefficients } \\
Model & & \multicolumn{1}{c|}{ B } & Std. Error & Seta & Sig. \\
\hline 1 & (Constant) & 13.350 & 3.570 & 3.740 &, 001 \\
& Kepemilikan Institusioanl & 8.120 & 6.230 &, 226 & 1.303 &, 199 \\
& Return On Asset & 67.844 & 6.635 & 1.157 & 10.226 &, 208 \\
& Corporate Social Responsibility & -27.224 & 8.249 & -0.654 & -3.300 &, 517 \\
\hline
\end{tabular}

a. Dependent Variable: Abs_ut

Sumber : data penelitian diolah, 2018

\section{HASIL DAN PEMBAHASAN}

Untuk menguji pengaruh variabel intervening, digunakan metode analisis jalur (path analysis). Model penelitian ini dikembangkan dalam diagram alur untuk memudahkan melihat pengaruh- pengaruh variabel yang sedang diuji. Analisis jalur merupakan perluasan dari analisis regresi linear berganda, untuk menaksir kausalitas antar variabel yang telah ditetapkan sebelumnya berdasarkan teori (Ghozali,2014)

\section{Pengujian Analisis Jalur Sub-Struktur 1}

Pengujian Sub-Struktur 1 digunakan untuk menguji pengaruh Kepemilikan Konstitusional $\left(X_{1}\right)$, 
Return On Asset $\left(\mathrm{X}_{2}\right)$ terhadap Penghindaran Pajak (Y).

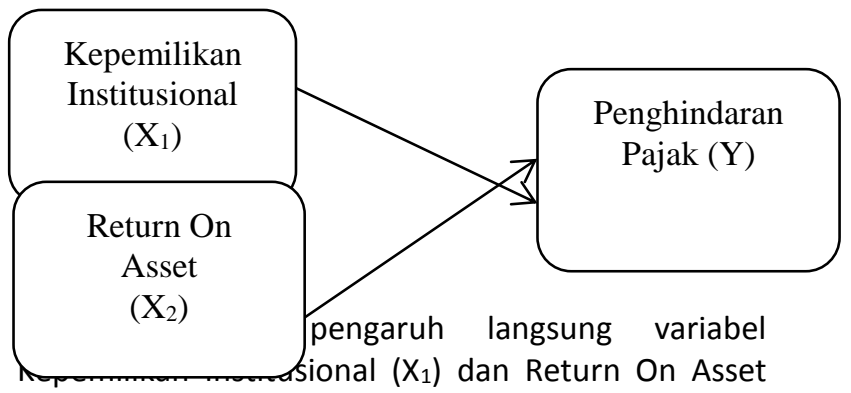

Gambar 3. Sub Struktur

$\left(X_{2}\right)$ terhadap Penghindaran Pajak dapat dilihat

melalui table berikut :

Tabel 4 Hasil Analisis Jalur Sub Struktur 1

Coefficients $^{\text {a }}$

\begin{tabular}{|c|c|c|c|c|c|c|}
\hline \multirow{2}{*}{\multicolumn{2}{|c|}{ Model }} & \multicolumn{2}{|c|}{ Unstandardized Coefficients } & Standardized Coefficients & \multirow[t]{2}{*}{$\mathrm{t}$} & \multirow[t]{2}{*}{ Sig. } \\
\hline & & $\mathrm{B}$ & Std. Error & Beta & & \\
\hline \multirow[t]{3}{*}{1} & (Constant) & 57.420 & 13.436 & & 4.274 & 0.000 \\
\hline & Kepemilikan Institusioanl & 0.069 & 0.259 & 0.0 & 0.267 & 0.791 \\
\hline & Return On Asset & 531.852 & 32.411 & 1.1 & 16.410 & 0.000 \\
\hline
\end{tabular}

a. Dependent Variable: Penghindaran Pajak

Sumber : data penelitian diolah, 2018

Dari tabel diatas terlihat bahwa nilai signifikansi variabel kepemilikan institusional adalah sebesar $0.791>0.05$, sehingga $\mathrm{H} 1$ gagal diterima yang berarti kepemilikan institusional tidak berpengaruh terhadap penghindaran pajak. Hasil penelitian ini sama dengan hasil penelitian yang dilakukan oleh Dewi dan Jati (2014) serta Annisa dan Kurniasih (2012) yang berpendapat bahwa tidak terdapat pengaruh antara kepemilikan institusional dengan penghindaran pajak. Pemilik institusional memiliki insentif untuk

Hasil penelitian ini sejalan dengan hasil penelitian yang dilakukan oleh Wirna (2014) bahwa ROA memiliki pengaruh signifikan terhadap penghindaran pajak. ROA merupakan suatu indikator yang mencerminkan kinerja keuangan perusahaan, semakin tinggi nilai ROA maka semakin baik kinerja keuangan perusahaan. Kinerja keuangan juga dikaitkan dengan laba yang merupakan dasar pengenaan pajak penghasilan. Perusahaan yang memperoleh peningkatan laba maka akan mengakibatkan beban pajak yang ditanggung oleh perusahaan semakin tinggi, maka ada kemungkinan perusahaan melakukan upaya penghindaran pajak guna meminimalisir beban pajak. memastikan bahwa manajemen membuat keputusan yang dapat memaksimalkan kesejahteraan pemegang saham institusional sehingga hanya berfokus pada manajemen laba, sehingga kepemilikan institusional tidak berpengaruh pada nilai penghindaran pajak. Sebaliknya, variabel Return On Asset yang digunakan penulis untuk menggambarkan kinerja perusahaan memiliki nilai signifikansi $0.000<0.005$, yang berarti bahwa return on asset memiliki pengaruh terhadap penghindaran pajak

\section{Pengujian Analisis Jalur Sub-Struktur 2}

Pengujian sub struktur 2 dilakukan untuk menguji pengaruh tidak langsung Kepemilikan Institusional $\left(X_{1}\right)$ dan Return On Asset $\left(X_{2}\right)$ terhadap Penghindaran Pajak (Y) melalui Corporate Social Responsibility (Z) dengan model sub-strutural 2 sebagai berikut : 


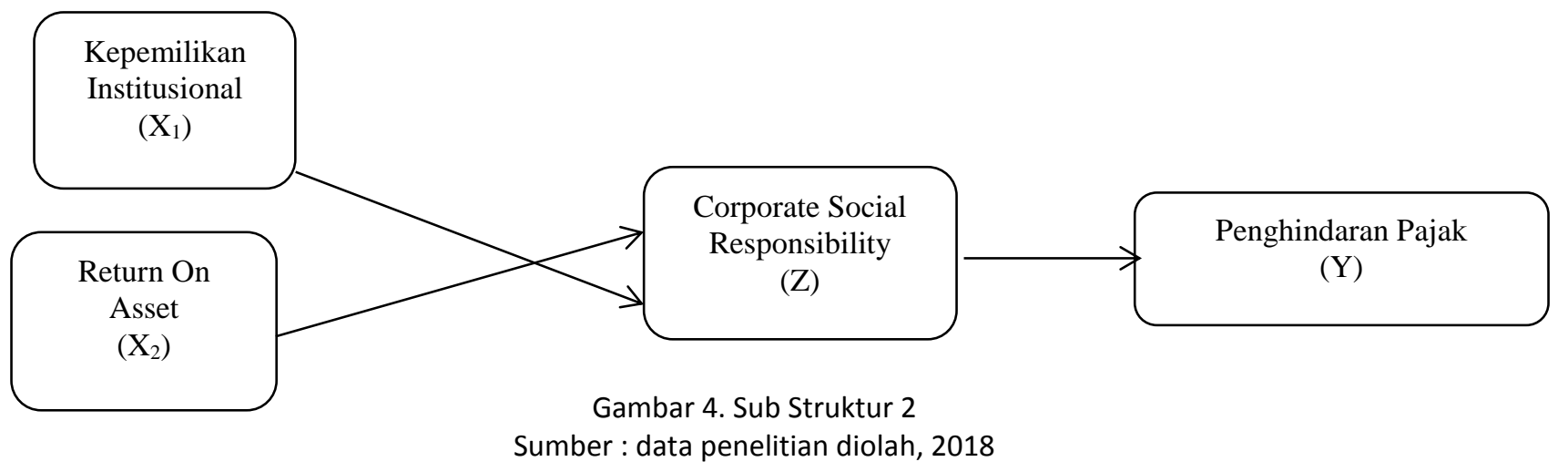

Hasil penelitian pengaruh Kepemilikan Institusional dan Return On Asset terhadap Penghindaran Pajak melalui Corporate Social Responsibility dapat dilihat pada table dibawah ini :

Tabel 5

Hasil Analisis Jalur Struktur 2

Coefficients $^{\text {a }}$

\begin{tabular}{|c|c|c|c|c|c|c|}
\hline \multirow{2}{*}{\multicolumn{2}{|c|}{ Model }} & \multicolumn{2}{|c|}{ Unstandardized Coefficients } & Standardized Coefficients & \multirow[t]{2}{*}{$\mathrm{t}$} & \multirow[t]{2}{*}{ Sig. } \\
\hline & & $\mathrm{B}$ & Std. Error & Beta & & \\
\hline \multirow[t]{4}{*}{1} & (Constant) & ,307 &, 041 & & 7.409 &, 000 \\
\hline & Kepemilikan Institusioanl &, 007 &, 001 & ,78 & 10.801 &, 000 \\
\hline & Return On Asset &, 362 &, 137 & ,19 & 2.641 & 011 \\
\hline & Corporate Social Responsibility & -100.975 & 32.152 & -0.41 & -3.141 & 003 \\
\hline
\end{tabular}

a. Dependent Variable: Penghindaran Pajak

Sumber: data penelitian diolah, 2018 
Dari table diatas terlihat bahwa variabel kepemilikan institusional memiliki pengaruh tidak langsung melalui corporate social responsibility sebesar 0.000 dan pengaruh langsung sebesar 0.791, sehingga memberikan pengaruh total sebesar $0.791>0.05$. Hal ini berarti $\mathrm{H}_{3}$ gagal diterima atau kepemilikan institusional tidak memiliki pengaruh tidak langsung terhadap penghindaran pajak melalui CSR. Hasil penelitian ini sejalan dengan penelitian yang dilakukan oleh Novita dan Djakman (2008) yang menemukan hasil bahwa kepemilikan institusional tidak berpengaruh terhadap CSR. CSR sebagai variabel intervening tidak dapat memediasi hubungan antara kepemilikan konstitusional dengan penghindaran pajak sehingga kepemilikan institusional

tidak terbukti dapat mempengaruhi nilai penghindaran pajak baik melalui CSR maupun secara langsung

Variabel Return On Asset memiliki nilai signifikansi atas pengaruh tidak langsung sebesar 0.011 dan nilai signifikansi atas pengaruh langsung sebesar 0.000 sehingga menjadi $0.011<0.05$. Hal ini berarti $\mathrm{H}_{4}$ diterima yaitu ROA memiliki pengaruh terhadap penghindaran pajak melalui corporate social responsibility. Hal ini sejalan dengan penelitian yang dilakukan oleh Yuniasih dan Wirakusuma (2007) yang menemukan bahwa ROA berpengaruh positif terhadap nilai perusahaan melalui CSR. Ini menunjukkan bahwa corporate social responsibility sebagai variabel intervening dapat memediasi hubungan antara ROA dengan penghindaran pajak sehingga dengan profitabilitas yang tinggi dan diperkuat dengan semakin tingginya kewajiban perusahaan memperluas tanggung jawab social akan memungkinkan perusahaan melakukan penghindaran pajak guna menjaga profitabilitasnya dengan tidak menambah beban pajak.

Variabel corporate social responsibility sebagai variabel intervening memiliki nilai signifikansi sebesar $0.003<0.005$. Nilai $t$ sebesar -3.141 menunjukkan bahwa pengaruhnya bergerak kea rah yang negatif. Hal ini berarti H5 diterima yaitu corporate social responsibility berpengaruh negatif terhadap nilai penghindaran pajak. Hal ini sejalan dengan penelitian yang dilakukan Yoehana (2013) yang menunjukkan hasil penelitian corporate social responsibility berpengaruh negatif terhadap penghindaran pajak. Hasil penelitian yang dilakukan oleh Muzakki (2015) juga menunjukkan bahwa CSR berpengaruh negative terhadap penghindaran pajak. Pajak dan CSR sama-sama ditujukan untuk kesejahteraan umum. Perusahaan yang melakukan penghindaran pajak dianggap tidak bertanggung jawab secara social dan bertolak belakang dengan prinsip CSR. Dengan demikian, semakin baik CSR yang dilakukan oleh perusahaan, diharapkan perusahaan juga semakin tidak melakukan penghindaran pajak.

\section{KESIMPULAN}

Berdasarkan hasil pengujian hipotesis, penelitian ini menunjukkan bahwa variabel kepemilikan institusional tidak berpengaruh terhadap penghindaran pajak secara langsung maupun melalui CSR dan variabel Return On Asset memiliki pengaruh terhadap penghindaran pajak melalui CSR, begitupula dengan CSR yang memiliki pengaruh negative terhadap penghindaran pajak.

Penelitian ini memiliki beberapa keterbatasan diantaranya adalah (1) jumlah data yang hanya 50 sample, peneliti selanjutnya diharapkan menambah jumlah sample dengan memperpajang periode penelitian. (2) Penelitian ini menggunakan sample perusahaan multinasional sub sector perkebunan, untuk peneliti selanjutnya akan lebih baik jika memperluas objek penelitian yang lebih sensitive terhadap pajak, misalnya pada perusahaan property. (3) bagi para peneliti selanjutnya yang akan melakukan penelitian berkaitan dengan CSR terhadap penghindaran pajak dapat menggunakan indikator CSR selain kepemilikan institusional saja, melainkan dapat menambahkan dengan indikator lainnya seperti komite audit, kualitas audit dan komisaris independen.

\section{DAFTAR PUSTAKA}

Annisa, N. A. dan L. Kurniasih, (2012), "Pengaruh Corporate Governance terhadap Tax Avoidance", Jurnal Akuntansi dan Auditing $8(2)$.

Chariri dan Ghozali, Acmad, (2007), Teori Akuntansi, Penerbit Andi: Yogyakarta

Dewi, Kristiana dan I Ketut Jati, (2014), “Pengaruh Karakter Eksekutif, Karateristik Perusahaan, dan Corporate Governance pada Tax Avoidance di Bursa Efek Indonesia", E-Jurnal Akuntansi ISSN 2302-8556 6.2: 249-260.

Erly Suandi, (2008), Hukum Pajak, Jakarta : Salemba Empat

Fahmi, Irham, (2012), Analisis Laporan Keuangan Cetakan Ke 2, Bandung : Alfabeta.

Ghozali, (2006), Aplikasi Analisis Multivariate dengan Program SPSS, Semarang: Badan penerbit UNDIP

Hendriksen E. and M. Van Breda, (1992), Accounting Theory, 5th edition, Irwin, Homewood, IL. 
Kasmir, (2012), Analisis Laporan Keuangan, Jakarta : PT Raja Grafindo Persada.

Kurniawati, F. A, (2013), “Pengaruh Profitabilitas, Leverage dan Ukuran Perusahaan terhadap Luas Pengungkapan Tanggung Jawab Sosial Perusahaan Pertambangan di BEI". Skripsi. Fakultas Ekonomi UNY.

Kuswadi, (2005), Meningkatkan Laba Melalui Pendekatan Akuntansi Keuangan dan Akuntansi Biaya, Jakarta : PT Elex Media Komputindo

Machmud, Novita dan Chaerul D. Djakman, (2008), "Pengaruh Struktur Kepemilikan Terhadap Luas Pengungkapan Tanggung Jawab Sosial (CSR Disclosure) Pada Laporan Tahunan Perusahaan: Studi Empiris Pada Perusahaan Publik Yang Tercatat Di Bursa Efek Indonesia Tahun 2006". Simposium Nasional Akuntansi 11. Pontianak.

Muzakki, (2015), “Analisis Pengaruh CSR dan Capital Intensity terhadap Penghindaran Pajak", skripsi, UNDIP, Semarang.

Ni Wayan Yuniasih dan Made Gede Wirakusuma, (2007), "Pengaruh Kinerja Keuangan Terhadap Nilai Perusahaan Dengan Pengungkapan Corporate Social Responsibility Dan Good Corporate Governance Sebagai Variabel Pemoderasi", Universitas Udayana, Bali.

Retno dan Pratinah, (2012), Pengaruh Good Corporate Governance dan Pengungkapan Corporate Social Responsibility Terhadap Nilai perusahaan (Studi Empiris Pada Perusahaan yang Terdaftar di BEI Periode 2007-2010), Jurnal Nominal, Volume 1, Nomor 1, Halaman 84.

Sembiring, (2005), Karakteristik Perusahaan dan Pengungkapan Tanggung Jawab Sosial: Studi Empiris pada Perusahaan yang tercatat di Bursa Efek Jakarta. Paper Presented at the Seminar Nasional Akuntansi, Solo.

Santoso, Singgih, (2012), Panduan Lengkap SPSS Versi 20, Jakarta: PT Elex Media Komputindo.

Wirna, Yola, (2014), “Pengaruh Profitabilitas, Leverage dan Corporate Social Responsibility terhadap Tax Avoidance", Jurnal Akuntansi 2.3.

Yoehana, (2013), "Analisis Pengaruh CSR terhadap Agresivitas Pajak". Skripsi. UNDIP. Semarang
Zanirah, D. N, (2015), Faktor-Faktor Yang Mempengaruhi luas Pengungkapan CSR Dalam Laporan Tahunan Perusahaan 2015.

www.idx.co.id

www.sahamok.com 